\title{
DIALOGIC ENGAGEMENT BETWEEN THE BIRTH STORIES IN LUKE 1 AND 2 AND SELECTED TEXTS FROM THE HEBREW BIBLE:
}

\author{
A BAKHTINIAN INVESTIGATION
}

Bettina Fischer

Stellenbosch University

\begin{abstract}
Part of a larger study of narrative strategy in the Gospel of Luke, this article makes use of Bakhtin's criteria of locus, form, and degree as an investigative tool to explore the intertextual presence of texts from the Hebrew Bible in Luke 1 and 2. To begin with, the presence of these texts is identified by name, quotation, and near-quotation in the gospel text. Having once established that, parallels in the use of form and sayings are identified between the older texts and the new host text. After that, the question of association in the collective memory of a verbal community is touched upon. In questioning as to what function the Hebrew texts perform in the gospel, their locus, form and degree of presence are identified. Having established how the similarities root the gospel text into the Hebrew canon, the older texts lending weight and legitimacy to the host text, the focus is then directed at the differences. This reveals how the gospel narrative, having anchored itself in canonical scripture is then set to diverge from it, ushering in unprecedented events and a new era in the relationship between God and his people.
\end{abstract}

Keywords: Dialogism; Intertextuality; Legitimization; Rooting in/diverging from Zechariah Isaiah

\section{Introduction}

An investigation into the dialogic nature of the Gospel of Luke is inevitably faced with a field that is far too large to be addressed within one article. To be comprehensive, it would have to cover a number of aspects, each of which would require a great deal of consideration. One aspect would be the internal dialogism of the text itself: Contending discourses made possible by different styles of language, ${ }^{1}$ by differing genres and by the interaction of a wide variety of characters. In this specific text, these are not limited to various social and political groups of this world, but they also represent the supernatural, posing a dialogue between the two spheres, between quotidian concerns and metaphysical, eternal matters.

Another aspect would be the dialogic interaction between the text in question and its historical socio-political environment. The context of the appearance of the Gospel of Luke, inestimable in its multiform vastness, was dominated by the supremacy of Roman rule (Rome being engaged in a power struggle of its own, both internally and in terms of keeping her provinces in subjection) which posed an overwhelming military and cultural threat to the

1 See IH Marshall, The Gospel of Luke: A Commentary on the Greek Text. Marshall distinguishes different styles of language throughout this commentary, for example (Marshall 1978: 39). 
inhabitants of the province of Judea in the first century $\mathrm{CE},{ }^{2}$ and, to a lesser extent, to Jews and early Christians living in other areas of the Empire. Hellenism, which, amongst other things, included the emerging mystery cults, can be seen as the prevailing cultural force. A practice that existed officially during this period was the folk festival of carnival in the form of the central Roman Saturnalia, as well as the Kronia in more remote, mainly Greek locations. ${ }^{3}$ One could contemplate the Lucan Gospel in terms of responding to some of these factors, as well as in terms of possibly eliciting a response to itself by whoever it is addressed to, be it the direct addressee, Theophilus (should he have existed outside the text), or a particular community. ${ }^{4}$

Thirdly, the dialogic dimension of the Gospel of Luke can be studied in terms of its interaction with other texts. This is the area that this article will focus on. But even here, many possibilities are open to examination, necessitating a selection. To begin with, there are the many references in the text itself to passages in books of Hebrew Scriptures, both overt and covert. Added to this, one can consider that this text was produced within an oral tradition, and has co-existed from the start with other gospels, canonical and apocryphal, sharing large sections of its content with them. Furthermore, it is unlikely that it would have been completely unaffected by texts of other genres of its own time and of preceding periods. Bakhtin places early Christian writing, including the Gospels, within the group of genres that he refers to as the Menippea, ${ }^{5}$ the body of texts that were not seen as part of the "high", classical genres of the literature of the time. It is possible that the Gospel of Luke, Menippean-like, freely incorporated aspects of other genres, including the classical genres, for its own specific purpose.

While the dialogism of a text as such, according to Bakhtinian theory, involves a response to both a previous utterance as well as to an expected future reaction to itself, this particular article will focus on the former. It will investigate relations between the Gospel of Luke and texts where an assumption of pre-existence can safely be made. An attempt to establish what the author may have had in mind in terms of eliciting a response to his text, or whether later texts actually appeared in response to it, would require a different sort of study. For this reason it is not possible here to regard the other three canonical Gospels other than in terms of comparison. Although all four Gospels clearly share a tradition, it is impossible to say with certainty which of them preceded which; which was responding to which. Scholarly opinion, on the whole, places the Gospels of Mark and Matthew at an earlier date to that of Luke, ${ }^{6}$ supporting the Two-Source Hypothesis. ${ }^{7}$ The fact that sections of those texts also appear in Luke has been regarded as a direct response to them. But there are also those who dispute this. ${ }^{8}$

This is the subject of The Jewish War by the first century historiographer, Josephus. See also Stern for an account of Josephus' angle when describing the events that led to the destruction of the Jerusalem Temple (Stern 1987: 71-78).

See Versnel, "Greek Myth and Ritual: The Case of Kronos" (Versnel 1986).

There is some debate concerning the identity of Theophilus (friend of God). Talbert states that the identity of the "most excellent Theophilus" is unknown, "possibly Christian" (Talbert 1986: 10-11). Craddock states that the name may be a literary device for addressing Christian readers. On the other hand, the address "most excellent" may point to the addressee being a Roman official (Craddock 1990: 15-16).

Bakhtin locates the early manifestations of novelistic writing (the genre that he judges to be the most accommodating in terms of dialogism) in texts of the Menippea. For a description of the Menippea in Bakhtinian terms, see Bakhtin's Problems of Dostoevsky's Poetics (Bakhtin 1984: 113-15).

Marshall 1978: 30-31.

The Two-Source Hypothesis holds that besides the sections taken from Mark, the common material between Matthew and Luke comes from a common source referred to as Q (from the German word Quelle, meaning source).

In a paper read by BE Wilson, entitled Synoptic Format Phenomena, at the 2001 International Meeting of the Society of Biblical Literature at the Pontifical Gregorian University in Rome, it was argued that all three of the writers of the synoptic Gospels each independently took their material from a common source (i.e. they were not 
The very fact of an uncertainty regarding this point makes it difficult to produce an argument based on the assumption of a conscious intertextual response on the part of the writer of the Gospel of Luke to any of the other three, even though this may well have been the case. ${ }^{9}$

Texts that exist outside the Gospel of Luke that can be identified within the Gospel text itself, either by name or direct quotation, where there is no doubt as to priority, are certain books within the canon of Hebrew Scripture. As this overt identification can be taken as proof of a definite intertextual involvement on the part of the Gospel with sections of these books, it is possible to assume an extension of this involvement to covert usage as well, providing, that is, that the corresponding sections can be definitively identified.

This article will focus on the dialogic interaction between the birth narratives in Luke 1 and 2 and selected sections of the Hebrew Bible. For the sake of clarity, I shall use the term intertextuality ${ }^{10}$ when referring specifically to the dialogic relation between texts, while using the word dialogism for the phenomenon as a whole.

\section{Representation of Another's Discourse within a Text according to Bakhtin}

According to Bakhtin, there are various ways in which the discourses of others can be represented within a text - the author making use of them to further the aims of his own discourse. He puts forward three considerations when approaching this phenomenon. The first is a question of locus. Where in the text is the other's voice encountered? Is it at the object under discussion itself, as in the case of direct or indirect polemic? Or, is it an encounter with various voices that surround the object, past utterances, that is, a conflict between various substitutable denominations of the same object? Or is it encountered in the potential (future) voice of the expected respondent? An example of this would be rhetorical discourse. ${ }^{11}$

A second consideration is the question of form. For example, is the voice of the other represented in the form of a particular character's speech? In this case one would look to see whether the author treats it as a passive object, part of his own discourse, or whether the voice of the character maintains a certain autonomy concerning the subject matter, thus standing in a relationship that resembles a dialogue with the discourse of the author. Or, does the voice of the other appear in the form of a direct quotation from another text? Is it in the form of imitation (where the other's voice is absorbed into the voice of the author), or in the form of stylisation (where the other's voice is presented as that of another, the voice of the author identifying itself with it, using it as a reinforcement of his own discourse), or in the form of parody (where the voice of the other is also presented as that of another, but, in this case, the author's voice clashing with it by means of ridicule)?

The third consideration concerns the varying degree of the presence of the other in the text. There can be full presence as in the case of direct dialogue. At the other end of the spectrum the voice of the other does not materially appear in the text: Nevertheless, it can, and has been summoned into the text because it exists in the collective memory of a given verbal community. This is the case when parody or stylization is made use of. The voice that is

directly based on one another). The common source is a set of teaching notes in Greek called the Greek Logia. These, in turn, had originated as a translation of the Aramaic Logia of the Papias tradition. See also Talbert (1986: 7), who also does not assume the priority of Mark. See also SG Wilson, who, in pointing to an increasingly vocal minority as to the inability of the Two-Source Hypothesis to explain the synoptic problem, does not see the necessity for the adoption of any hypothesis about the relationship of the synoptic Gospels for a consideration of Luke's narrative (Wilson 1983: 13).

9 Luke (1:1) mentions previous accounts, but does not identify these by name.

10 Todorov points out what he sees as a difficulty in Bakhtin's use of the term dialogism, also making use of the term intertextuality. My use of both terms differs somewhat from Todorov (Cf. Todorov 1984: 60).

11 Bakhtin "Slovo v romane"in Todorov bibliography (1984: 72). 
actualised in the text is presented in the light of another voice, even though this second voice is not realized, remaining outside the text itself. ${ }^{12}$

Between these two extremes there is an intermediary degree of presence of the other's voice, which Bakhtin refers to as hybridisation. In this case the text belongs to a single speaker in terms of its syntax and composition, while, nevertheless, containing a second voice in terms of style and worldview expressed within it. ${ }^{13}$

\section{Intertextuality between the Gospel of Luke and Books from the Hebrew Bible ${ }^{14}$}

It is hardly necessary to point out the overwhelming presence of the voices of the Hebrew Bible in the Gospel of Luke, voices that are themselves in intertextual relationship with each other. Simply by glancing at the Gospel text one is struck by overt references to the older texts. Actual books of the older canon are mentioned by name, such as the Law of Moses (Lk 2:22) and the Book of the prophet Isaiah (Lk 3:4). The protagonist, Jesus, specifically refers to the Law of Moses, the Psalms and the Prophets as authoritative texts at the end of the Gospel (Lk 24:44). Sections of the Hebrew Bible texts appear in the Gospel in the form of quotation without specifically naming the source (Lk 4:4, Deut 8:3; Lk 4:8, Deut 8: 3; Lk 4:10-11, Ps 91:11-12; Lk 4:12, Deut 6:16), while others are named and quoted (Lk 3:4-6, Is 40:3-4). Furthermore, both the narrator and characters in the Gospel, evidencing the author's assumption of a general pre-knowledge of the older texts, mention characters from the Hebrew canon. Examples are Aaron (Lk 1:5), David (Lk 1:32), Abraham (Lk 3:8), Elijah (Lk 1:17), Elishah and Naaman (Lk 4:27), Jonah (Lk 11:29-32). Characters from the Hebrew Bible, namely Moses, Elijah and Satan, actually appear in the Gospel (Lk 9: 30,4:1-12).

Further evidence of the connection can be seen in the Palestinian setting of the Gospel. Jerusalem and the Temple play a major part at the beginning and at the end of the narrative. In addition there are references to festivals, such as the Passover, and character names, such as Zechariah, John, Mary, Jesus, and others, who have counterparts in the older canon. Lest there be any further doubt as to the author's intention of ensuring a direct, continuous link between the narrative that appears in the Hebrew canon and the narrative of the Gospel of Luke, one need only look at Luke 3:23-38, where the genealogy of the protagonist, Jesus, confirms the Angel Gabriel's statement (Lk 1:32) as to the latter being a descendent of David, thus establishing this character as the embodiment of the link between the old canon and the new Gospel text.

Apart from these easily observable features that are evidence of an intertextual relationship between Luke and the older texts, there are other less obvious connections, which, nevertheless, have a profound impact on the discourse of the Gospel. To begin with it is noteworthy that the Gospel follows the example of the books of the Hebrew Bible in quoting, or paraphrasing, passages from the various books of the canon that have gone before. These quotes, evidencing an intertextuality between the various texts of the older canon, open the potential for a larger or lesser engagement between them. They can serve either to reinforce or to challenge a particular point, or they may simply reinforce the sense of continuity and legitimacy of a particular text. The Gospel, in following this example, takes over this whole potential for intertextuality between itself and the texts of the Hebrew canon.

Bakhtin in Todorov bibliography (1984:73).

Bakhtin in Todorov bibliography (1984:73).

It must be noted here that the author of Luke made a great deal of use of the Septuagint (LXX) translation of the Hebrew canon (Marshall 1978:53). I shall thus refer to this translation where I feel it is relevant, for example, when the discussion revolves around a particular word or a matter of style. 
A parallel use of form is another way in which the Gospel interacts with these older texts, an example being, amongst others, the use of genealogy (Gen 5 and 1, 1 Chr 1-9, Lk 3:23-38). Further examples are the use of specific formulations and the way the narrative is placed into history. Both the latter can be seen in the following example: "In the fifteenth year of the reign of the Emperor Tiberius ... the word of God came to John son of Zechariah in the wilderness" (Lk 3:1-2), to be compared to Zech 1: 1, "In the eighth month, in the second year of Darius, the word of the Lord came to the prophet Zechariah son of Berechiah son of Iddo." Another example is the repetitive use of the phrase "on that day", referring to Yahweh's Day of salvation in Zechariah (e.g. Zech 14:20), and the day that the Son of Man will be revealed in the Gospel (e.g. Lk 17:31).

What is striking at the beginning of the Gospel, as the narrative gets on to its feet to reach the point of Jesus' ministry, are the multiple strands that root it in the Hebrew canon. Possibly for the purpose of legitimisation, the later text is placed in close proximity to the older, already canonized narrative. By means of what could be called a grafting technique, it is implied that the Gospel narrative is a continuous development of the narrative of the older texts.

I shall now present a close intertextual reading of the first two narratives in Luke, namely the Annunciations of John and Jesus in order to demonstrate the multiple use, at times simultaneously, that the Gospel makes of the texts from the Hebrew Bible.

\section{The Annunciations of John and Jesus (Lk 1:5-38)}

Miraculous conceptions as such hint at an intertextual connection with the Hebrew Bible, being nothing new to anyone who is even vaguely familiar with that tradition. The opening narrative of the Gospel recounts two parallel stories, each announcing an unusual conception and birth. Recounted directly after one another, these two stories, thus juxtaposed, invite comparison. The first announcement, proclaiming the coming event of John's miraculous conception, entrenched in the framework of the current religious establishment, has counterparts in Hebrew Bible tradition, as will be shown. ${ }^{15}$ John's father, acting within the sanctuary of the Jerusalem Temple, is a priest, while John's mother (too old to conceive a child) is also of priestly descent. John himself, who is to become the agent who inaugurates the major legitimising event of Jesus' baptism, is thus already fully legitimised in terms of mainstream Jewish tradition, that is, already before his conception, even before the Angel Gabriel announces his special role in the future. The announcement is then linked in multiple ways to the second announcement, the conception of Jesus, infusing the latter with its own legitimacy. Marshall points out the parallels in these two stories: both announced events are initiated by divine intervention, both are announced by the angel Gabriel, and both are given a confirmatory sign (Marshall 1978: 49). To this one can add that in each case a special, God-sanctioned destiny is foretold for the child to be born. ${ }^{16}$ A further connection between the two stories is the family relationship between the mothers of the two babies to be born, linking Jesus' family to the priestly family of John (Lk 1: 36). Thus the announcement of the conception of Jesus, strange on its own (as I shall point out later), is anchored in the legitimacy of the more traditional announcement of the conception of John, which, in turn, is anchored in the Hebrew Bible narratives.

15 Mary's, song, for example (Lk 1:46-55), evidences echoes of Hannah's prayer in the Hebrew Bible (1 Sam 2).

16 Robbins, in demonstrating parallels in Josephus' Moses and the Gospel of Luke and Plutarch's Alexander, points to this feature, combined with a prophecy that this child (Jesus) will also be the downfall of many, as one that links Luke to Jewish biographical history on the one hand, and Graeco-Roman historical biography on the other (Robbins 1981: 294-6). One can note here that the "downfall of many" does not feature in the prophecy concerning John's future, linking John firmly to the prophecies concerning his predecessors in the Hebrew Bible in terms of miraculous conceptions, which also do not feature "the downfall of many." 
In Bakhtinian terms these two short narratives are in a dialogic relationship with each other, for, while emphasis has thus far been put on the parallels, there are divergences as well that serve to mutually illuminate them, this process ultimately carrying the crucial element of the Lucan discourse. While the story of John's coming conception strengthens the legitimacy of the second announcement, the latter also uses it as a point of departure from which a totally new story is heralded. For a better understanding of the relationship between these two announcements, it is worth examining the role of the Hebrew Bible involvement more closely.

\section{Miraculous Conceptions}

In terms of conceptions brought about by divine intervention, the Gospel story roots itself in a tradition that goes all the way back to Genesis, examples being the story of Abraham and Sarah (Gen 17:19, 21:2-3), and that of Jacob and Rachel (Gen 30:22). The phenomenon can then be further traced in Judges in the story of Manoah and his wife (Judg 13:2), and in 1 Samuel, the story of Hannah and Elkanah (1 Sam 1:1-28). ${ }^{17}$ These stories share a number of features. In each case the child that is born is destined to play a special role in the life of the people of Israel, featuring at a crucial point in its history, a point when a major change is about to take place. Isaac is the son with whom God makes the covenant (Gen 17:21). Joseph, saving his people from starvation, is responsible for bringing them into Egypt, while Samson will deliver Israel from the Philistines (Judg 2:5). Samuel, the first of a line of prophets, is instrumental in inaugurating Israel's transition from a society ruled by judges to a monarchy (1 Sam 8:22). The Gospel Annunciation stories rank themselves with these Hebrew Bible stories, implicitly claiming the imminence of a momentous event that will radically change the lives of the people of Israel.

Other features that appear in the Gospel announcements are found in all or some of these earlier models. The miracle in the earlier models hinges on the fact that the mothers are barren, the barrenness not being a form of divine punishment, even though the women suffer under human judgement on its account. God's intervention opens the womb in order that a child of special significance to the people of Israel may be born. Disbelief in the announcement, in part on account of the advanced age of the prospective parents, features both in the case of Abraham and in that of Zechariah. In the same two stories concerning Isaac and John, as well as that of Jesus, the name of the children is pre-ordained by divine will. As the significance of Isaac lies in the fact that God chose him with whom to make his covenant, there could be a foreshadowing implication that the divine plan concerning John and Jesus would also concern matters of covenant between God and his people. This is confirmed shortly afterwards in the Song of Zechariah (Lk 1:72). ${ }^{18}$ Another foreshadowing can be seen in the question of human sacrifice that features prominently in the Isaac story.

The fact that the announcement of the coming conception is made by a divine agent (or a God-inspired human agent) is another parallel feature between the various stories. In the case of Abraham, God himself tells him, while at a later stage three men who turn out to be angels tell him again. Manoah's wife is told by a man who turns out to be an angel, while the priest, Eli acts as intermediary in the case of Hannah. The Angel Gabriel announces the conception of both John and Jesus. The divinely inspired manner of communication vouches for the truthfulness of the announcements.

17 As mentioned earlier, Mary's song ( $L k$ 1:46-55) evidences echoes of Hannah's prayer in the Hebrew Bible (1 Sam 2).

18 Diatheke in Greek. Cf. LXX Gen 17:21, diatheke. 
A third feature is the Naziritic element, presumably for the purpose of purity and sanctification. ${ }^{19}$ Manoah's wife (Samson's mother) is told not to drink wine or strong drink, or eat anything unclean, and that she must raise her son as a Nazirite, not allowing a razor to come to his head (Judg 13:4-5). Hannah (Samuel's mother) promises God that, should she be given a male child, she will dedicate him to God. He will live as a Nazirite, drinking neither wine nor intoxicants, and his head shall not be touched by a razor (1 Sam 1:10). Gabriel orders Zechariah not to allow John to drink wine or strong drink, not specifically spelling out the Naziritic identification as such; nevertheless, the allusion to it connects it to the case of Samson insofar as in each case this order is issued directly before the sanctified future role of the child is announced (Lk 1:15, Judg 13:5).

In terms of Bakhtin's scheme of how the other's voice is appropriated into a given text, one could say that in terms of the locus of the intertextual encounter the Hebrew Bible texts are situated at the point of the future response of the receiver of the Gospel text. They reinforce the host text, serving proactively to counter any possible disbelief in the veracity of the miraculous recounted in it. Heavy emphasis, in terms of Jewish tradition, is thus placed on the legitimacy and significance of the two characters to be born.

In terms of the form of the encounter, in Bakhtinian terms, one could say that the Hebrew Bible texts, appearing both in the narrative voice and in the voice of the characters, are formally subsumed in the voice of the author of Luke as in an imitation. The older texts are not mentioned by name as such, nor do they appear as a quotation. However, one could say that the texts are there just under the surface of the author's voice, present in what Bakhtin would call the intermediary degree $p$ - one of hybridisation. They are not subsumed in such a way that they are not recognisable. The names of two important Hebrew Bible characters (outside the Hebrew Bible conception stories) are referred to by Gabriel, one in each announcement, each in conjunction with the respective character's future role. John's role is linked to that of Elijah, Jesus' to that of David. The former is thus linked to prophetic activity, the latter to kingly rule. Furthermore, character names in the Gospel text are significant, not only in terms of their meaning, ${ }^{20}$ but in terms of their being the names of Hebrew Bible characters that can be seen to have relevance to the story at hand. Zechariah can be seen to have his counterpart in the Hebrew Bible prophet. The name Elizabeth goes back to the name of the wife of Aaron, reinforcing the latter day Elizabeth's priestly connection. Mary has her counterpart in Miriam, ${ }^{21}$ the sister of Moses and Aaron, the woman who helped to facilitate Moses' fulfilling his monumental role in releasing the Israelites from the bondage of Egypt. Jesus has a significant counterpart (apart from the man who led the children of Israel into the Promised Land) in the high priest, Joshua, in the book of Zechariah, ${ }^{22}$ implying, together with the reference to David, a combined role of regal and priestly function.

Apart from the situational parallels with Hebrew Bible texts evident in the Gospel, there are also a number of formulaic parallels, for example, "Then God remembered Rachel and God heeded her and opened her womb" (Gen 30:22), which can be compared to Hannah's story, "The Lord remembered her" (1 Sam 1:19) and to Elizabeth's situation "for your prayer has been heard. Elizabeth will bear you a son" (Lk 1:13). ${ }^{23}$ Another such detail is "drink neither

19 See Numbers 6:1-21 for the Nazirite vow.

Zechariah - Yahweh remembers; John - gracious gift of God; Gabriel - man of God; Mary - exalted one; Joseph

- May God add; Jesus - Yahweh saves.

21 Mary is Mariam in the Gospel. Miriam is Mariam in LXX.

22 Jesus is Jesus in the Gospel. Joshua is Jesus in LXX.

23 Marshall is of the opinion that Zechariah's prayer was not for a son, but possibly for the coming of the Messiah (Marshall 1978: 56). However, considering the fact that the announcement is that of a son, and taking into account the Hebrew Bible precedents that are heavily alluded to, I think it more likely that Zechariah's prayer would have 
wine nor toxicants, and the head shall not be touched by a razor" (1 Sam 1:10, Judg 13:5, Lk1:15), as shown above, and, concerning the possibility of the seemingly impossible in terms of conceiving a child, the angel's "Is anything too wonderful for the Lord?" (Gen 18:14), ${ }^{24}$ can be compared to Gabriel's "For nothing will be impossible for God" (Lk 1:37).

In terms of Bakhtin's criteria of degree, one can say that the older text does not appear in full presence, as in a direct dialogue, or quotation, but is summoned by virtue of its existence in the memory of a particular verbal community, namely the community that is familiar with the Hebrew Bible tradition. The receiver of the Lucan text does not necessarily need a close knowledge of each book of the Hebrew Bible in order for this intertextuality to operate. The stories of Isaac, Joseph, Samson and Samuel, referring to monumental national figures that have played a crucial part at points of drastic change in the history of Israel, would have been generally recognisable. The author of Luke aligns John, and, by extension, Jesus, to these figures, implying another impending drastic change. ${ }^{25}$

\section{Differences between the Annunciations of the Births of John and Jesus}

Having established the parallels between the two NT announcement stories and the Hebrew Bible models, it is of interest to look now how the story of Jesus differs from that of John, and, by extension, to the Hebrew Bible models. First of all one can note that the announcement of the conception of Jesus follows hot on the heels of that of John. It is directly linked to it, the effect being one of duplication in significance. While the Hebrew Bible stories stand on their own, Jesus' story is inaugurated by John's, the latter functioning as a forerunner, which is the function that is assigned to the character, John, in relation to Jesus in the story as a whole. The implication is that Jesus is the greater of the two, also surpassing the monumental characters in the Hebrew Bible models. The latter had not been ushered in in this way. The phenomenon of the forerunner preparing the way lends a regal connotation to the figure of Jesus, which is reinforced by the words of the heavenly messenger, Gabriel: "the Lord God will give him the throne of his ancestor David" (Lk 1:32).

The second difference is that Jesus' Annunciation does not take place in the Jerusalem Temple, or even in its surroundings, the area of what had been Judah (in the post-exilic era). It takes place in Nazareth in Galilee, outside the inner priestly domain of Judaism. It is the area from where Jesus is to begin his ministry. This geographical divergence from John's case implies and forecasts a spreading out from the constriction of the Temple, its surroundings and, by implication, its power structure. Linking up with the Hebrew Bible models discussed above, it reaches back to Genesis, a book that is set in legendary time, one that predates the cult in Jerusalem, featuring a wider, more universal dominion of God's reign. A further factor that could be seen as forecasting a challenge to the status quo of the current, priestly power structure is that, unlike John's parents, Mary and Joseph are not of priestly stock, but are of a family that is descended from David. This could recall the exilic and post-exilic restoration period, characterized by the power struggles between priestly authority and the drive for monarchical rule as alluded to in, amongst others, in the books of Haggai and Zechariah. ${ }^{26}$

been for the issue at hand, the birth of a son. The fact that he is primarily filled with disbelief does not necessarily cancel out his longing. Also, the disbelief could be seen as part of the divine plan to necessitate a drastic sign for the sake of the people to draw attention to God's intervention.

The Greek text of the Gospel has the same wording as the LXX translation of the Hebrew text, except that the phrase appears in the form of a question in Gen 18:14, while it is a statement in Lk 1: 37.

For another description of the intertextual link between the Gospel of Luke and the Hebrew Bible see Joel B Green (1995: 24-28).

See Hanson (1975: 209-269), the chapter on the origins of post-exilic hierocracy. 
The principal difference between the two Annunciation stories is that of the conception itself. Unlike the mothers in the other stories, who have not conceived previously because of barrenness, Mary's reason for not having conceived thus far lies in her virginity. She is not barren and has not prayed for a child. There is a sense of untouched purity and youth, God's intervention initiating something completely new. Gabriel's description of the manner of the coming conception also constitutes a change from the old. The conception will not happen as a result of physical intercourse with a man, but by means of the Holy Spirit and the power of the Most High (Lk 1:35), in other words, by supernatural means. Before the receiver of the text can recover from this shock he or she learns that the issue of this conception will be holy, and will be called the Son of God. This appellation was not applied to any of the other miraculously conceived characters, who, although chosen by God for a specific role, were conceived in the natural way and remained strictly human. The story of the conception of Jesus, initially legitimised by that of John and the Hebrew Bible predecessors, has now moved into a different dimension, a dimension that links the sphere of the supernatural to the realistic earthly sphere in the form of the child to be born. The manner of divine intervention represented here is of an unprecedented kind within the Hebrew Bible tradition. ${ }^{27}$ Having first established itself within that tradition, it then breaks with its pattern.

What has been described thus far is a fairly easily detectable presence of texts from different books of the Hebrew Bible in the Gospel of Luke. In appropriating them, primarily for legitimising purposes, the author of the latter has absorbed them into his text, identifying his own voice with them to begin with, in order to strengthen the credibility of the story of the coming conception of Jesus, which, on its own, might come across as an incredible, isolated incident. At the same time, however, there is also ambivalence towards these old texts in the authorial voice as a divergence from their pattern comes to the fore in that same story.

\section{The Appearance of the Angel (Isa 6:1-13, Lk 1:10-20)}

The conception stories are not the only Hebrew Bible texts that operate in the Gospel Annunciation stories. Another such presence, one that also has a significant impact on the discourse of the Gospel of Luke, can be found on a less obvious level. When the angel appears to Zechariah (Lk 1:10-20), one is reminded of the story of Isaiah (Isa 6:1-13), in which the prophet recounts a vision of God on a throne attended by seraphs, one of whom approaches him. The setting is the same as the scene described in Luke. Other parallels include a priest in the sanctuary of the Temple at a holy moment, an angel conversing with him, terror on the part of the human as a result of the proximity of the divine presence, something burning, and an instruction given by the angel to the human. In each case the angel performs an action that physically affects the human in terms of speech. In Isaiah's scene there is a promise of eventual communal healing after repentance, but only after great devastation. In the angel's message to Zechariah the imminent coming of the Lord is foretold for which the people must be prepared through repentance. In both cases one can detect the pattern of salvation to come, which must be preceded, first, by the purification of the human agent, who must then, in turn, persuade the people to repent, that is, to be purified to prepare for the event of God's saving action. While

27 There are reports of similar births in the Graeco-Roman tradition. The births of Alexander the Great and Julius Caesar were claimed to be the result of their mothers having been impregnated by gods. See Robbins, who suggests that this particular feature (the protagonist being generated by God (the Holy Spirit)) is a crucial element in showing that the Gospel of Luke has moved beyond the topoi of Jewish literature into the literary world of Graeco-Roman writings such as Plutarch's Alexander in terms of the portrayal of the protagonist (Robbins 1981: 305-6). Thinking along Bakhtinian lines one could add here that the break from Hebrew Bible tradition in this respect is a literary device, deliberately interacting dialogically with it to further the Lucan discourse. 
Isaiah is the recipient of the message, as well as the future conveyor of it, Zechariah, as the receiver of the message, is punished and disabled, the onus of conveying the message of repentance resting on his future son, who, from the start, must keep himself, nazaritic-like, pure for this task.

One might argue here that since the Isaiah text is not mentioned by name, these parallels in the two scenes are coincidental, and that, while comparisons can be drawn, there need not necessarily be an actual connection, an actual employment of the older text by the Gospel text. Strictly speaking that could be true, but it is not likely. Reading further into the Gospel, there is a clear indication of the presence of the Book of Isaiah, both by name and by quotation (Lk $3: 3-5,4: 17-19)$, showing that the author of Luke consciously employed this text on the overt level. An extension of this use on the covert level is conceivably possible.

The scene of Isaiah's experience is infinitely more impressive than that of Zechariah. The former actually has a vision of God himself surrounded by worshipping attendants that are described in amazing visual terms (Isa 6:1-5). The presence of God, although it is only the hem of his robe that fills the Temple, ${ }^{28}$ causes a shaking of the pivots of the thresholds and fills the house with smoke. This implies that the divine presence is mighty and dangerous, sweeping everything that is unholy out of the way. The smoke carries the connotation of fire itself with its purifying effect. The seraph then actually applies a hot coal to cleanse the prophet's lips in order to blot out his $\sin$ (Isa 6:6-7).

The Gospel description of Zechariah's experience is a weak echo of the Isaiah story. God is not actually seen. The angel is given no physical description. Instead of the immensity of the divine presence in the form of the hem of the robe and the all-filling smoke, Zechariah has his vision at the time of the human activity of burning incense as an offering. While Isaiah confesses his sin and then, after having been cleansed, offers his willingness to serve, Zechariah shows disbelief in the message and is struck dumb as a temporary punishment. The angel disables him, the disability then being used by the divine power to carry the truth of the intervention to the people, to enable them to believe that it has occurred. Nevertheless, the Isaiah vision is summoned up in the Gospel story as the archetypal version, giving the latter a framework of grandeur. Like the other Hebrew Bible models discussed above, it has a reinforcing effect on the legitimacy of the Annunciation of John. Although neither the proximity of God himself, nor his visible splendour are described in the Gospel, his imminence is felt by association. Thus when the angel says: "I am Gabriel. I stand in the presence of God" (Lk 1:19), the imagination of anyone familiar with the old story can summon up the divine scene, reinforcing an impression of awe in terms of God's presence behind the angel that brings the message.

Thinking along Bakhtinian lines in terms of dialogic interaction between the two texts one would ask why the author of Luke, keen to emphasize the significance and veracity of his story, should give this rather anticlimactic version of the older model. The answer to this can be found in what follows next. The Annunciation of the birth of Jesus (the protagonist) is presented as the scene that, according to the Gospel, is the most significant of all the miraculous conception scenes. While Isaiah features as the main character in the Hebrew Bible story in terms of the divine plan to inaugurate salvation, Zechariah and John are secondary figures to Mary and Jesus in the Gospel. The Isaiah scene underlies both Gospel announcements, grafting the two stories together on a deeper level. It is the scene featuring Zechariah and Gabriel that lends the encounter between Gabriel and Mary (at a location removed from the Temple) the sense of holiness by virtue of association. Featuring as a comparatively

28 In LXX there is no mention of the hem of the robe. It simply states that the "house was full of his glory" (Isa 6: 1). 
depressed version of the older story, it acts as the link between Isaiah's vision and that of Mary, at the same time allowing the latter to be highlighted.

The Temple no longer necessary for legitimization, the scene between Mary and Gabriel is placed in a new location that is only specified in broad terms. There is a direct, uncluttered interaction between the angel and the human. Mary takes over the role of Isaiah in relation to the divine intervention. However, as the human agent for the plan of salvation, unlike Isaiah, she does not have to be purified, as she is young, innocent, and has never been touched by a man. She is pure. After initially expressing wonder on account of what appears to be a physical impossibility as to her ability to fulfil the angel's prophecy (unlike Zechariah, she is not punished for it!), she, like Isaiah, commits herself to becoming God's instrument: "Here am I, the servant of the Lord. Let it be with me according to thy word" (Lk 1:38), which can be compared to "Here am I: send me!"(Isa 6:8).

In this encounter between Mary and Gabriel, connected to the other Annunciation scenes as well as that of Isaiah by association, the author ushers in a new era. In declaring herself willing to be the servant of the Lord in this matter, however incredible it seems in terms of human reasoning, Mary, as a woman, follows the path of the prophet Isaiah in terms of faith in the power of the divine. However, the manner and content of her ordained service differs from that of Isaiah. She is not a prophet, nor a priest. She does not have to be purified. She will not be a messenger to persuade the people to repent to enable salvation to take place. Instead, she herself will be the locus through which salvation (later to be described as the Kingdom of God) will appear in human form in the person of Jesus. Instead of salvation being referred to simply in terms of its coming, as is the case in the older text, the manner and form of its coming is spelt out in the Gospel. Instead of eventual re-growth after near total destruction with God at a far distance in Isaiah, the divine world will enter the human world in human form through the womb of a woman in the Gospel.

In terms of dialogic interaction one could say that the author, while using the Isaiah text, transmitting a sense of momentous grandeur in terms of God's intervention in the Gospel, as well as introducing the issue of purification of the human agent, also challenges it by implication. Having first accepted and identified itself with the Hebrew Bible tradition, the discourse of the Gospel announces a radical change. The simplicity of the scene between Gabriel and Mary, as well as its distance from the Temple, together with the actual content of the message, proclaims that salvation will come in an unprecedented form that poses new challenges, shaking the very structures in which it roots itself. While Isaiah is the only one who sees God's proximity, eventual healing for the people being promised in the far future after much suffering, the imminent divine presence in human form amongst the people themselves is foretold in the Gospel Annunciations. In line with the Hebrew Bible prophets of old, Zechariah's son will "make ready a people prepared for the Lord" (Lk 1:17), while Mary's son is the coming salvation itself.

\section{A People prepared for the Lord}

The notion of the people having to be prepared for the coming of the Lord by repentance, featuring in the Annunciation of John (Lk 1:16-17), is a prominent theme in various Hebrew Bible texts. It is of primary importance in the scene with the seraph in the Book of Isaiah that has been discussed above. The intertextual link between these two texts concerning this notion is confirmed as the Gospel story progresses, surfacing by actual name and quotation (Lk 3:2-6, Isa 40:3-5).

Another Hebrew Bible prophet with the same notion of preparing the people for the coming of the Lord through repentance, namely Elijah, is mentioned by name in the Annunciation of 
John: "With the spirit and power of Elijah he will go before them, to turn the hearts of parents to their children, and the disobedient to the wisdom of the righteous, to make ready a people prepared for the Lord" (Lk 1:17). It turns out to be a near-quotation from the Book of Malachi: "Lo, I will send you the prophet Elijah before the great and terrible day of the Lord comes. He will turn the hearts of parents to their children and the hearts of children to their parents, so that I will not come and strike the land with a curse" (Mal 4:5-6). This can be seen as another example of the new text having appropriated a Hebrew Bible text in order to strengthen the legitimacy of its own discourse, while also diverging from it. As in the vision of the Temple scenes, the divine power in the older text features as much harsher than the one in the new text. John's birth and mission will bring joy to many in expectation of the coming of the Lord, while the coming of the Lord will be expected with fear in the case of Elijah, lest by finding the people unprepared in terms of repentance he will strike the land with a curse. What emerges from this also implies (as does the illusion to Isaiah) that the Lucan discourse points towards a new era in terms of God's relationship with his people, a relationship that will be on a more familiar, compassionate level. One could say that the point is given emphasis by means of duplication.

\section{Concluding Remarks}

This analysis of the involvement of texts from the Hebrew Bible in this minimal portion of the Gospel, featuring the two Annunciation stories, shows not only that the author must be familiar with the older texts, but also that he relies on that knowledge on the part of (at least some) of his readers and listeners, making it possible to engage in a dialogue between the Lucan text and the Hebrew Bible, as well as with the expected reader. A closer awareness of this intertextual dimension, by making use of Bakhtin's theory, reveals the considerable skill with which the author has crafted this introduction to Jesus' ministry, as well as the presence of various layers of associations that underpin the relatively simple surface narrative. The deliberate force with which the legitimacy of the figure of Jesus is established, forms a firm basis for the discourse of the text that follows. The multiple strands that link this small section of the text to the Hebrew canon serve to legitimize the narrative itself, implying that it is a continuation of the older narratives. The older stories lend the text grandeur and colour, establishing the fundamental discourse that the gospel first identifies itself with, to then enter into a dialogical relationship with it as it establishes its own discourse.

This exploration is only a beginning. The same kind of analysis can fruitfully be applied to other sections of this text as well. I have followed one of the multiple strands, the dialogic interaction between the Gospel of Luke and the Book of Zechariah[B I1], in another article. ${ }^{29}$

29 Fischer, Bettina, The Lord has Remembered: Dialogic Use of the Book of Zechariah in the Discourse of the Gospel of Luke, in Neotestamentica (37 (2), 2003. 


\section{BIBLIOGRAPHY}

Auerbach, Erich 1953. Mimesis, translated by Willard R Trask. Princeton: Princeton University Press.

Aune, David E 1987. The New Testament in its Literary Environment. Philadelphia:

Westminster Press.

Bakhtin, Mikhail Mikhailovich 1968. Rabelais and his World, translated by Helene Iswolsky. Cambridge, Massachusetts, London: MIT Press.

Bakhtin, Mikhail Mikhailovich 1971. Iz zapisej 1970-1971 godov: (Extracts from notes from the years 1970-1971).

Bakhtin, Mikhail Mikhailovich 1976. Problema teksta v lingvistike, filologii i drugikh gumanitarnykh naukakh, Opyt filosovskogo analiza (The problem of text in linguistics, philology, and the other human sciences) In Voprosy literatury 10 (1976)...Written 19591961.

Bakhtin, Mikhail Mikhailovich 1981. The Dialogic Imagination: Four Essays (Epic and the Novel, From the Prehistory of Novelistic Discourse, Forms of Time and of the Chronotope in the Novel, Discourse in the Novel), translated by Caryl Emerson and Michel Holquist (ed.) Austin: University of Texas Press.

Bakhtin, Mikhail Mikhailovich 1984. Problems of Dostoevsky's Poetics, translated by Caryl Emerson (ed.). Minneapolis: University of Minnesota Press.

Bauer, Dale M 1991. Feminism, Bakhtin, and the Dialogic. Albany: State University of New York.

Black, MC 1990. The Rejected and Slain Messiah who is Coming with his Angels: The Messianic Exegesis of Zechariah 9-14 in the Passion Narratives. PhD dissertation, Emory University.

Bocharov, Sergey 1994. Conversations with Bakhtin, translated by V Liapunov and S Blackwell. In Publications of the Modern Language Association of America, Vol. 109, pp.1009-24.

Brawley, Robert L 1995. Resistance to the Carnivalization of Jesus: Scripture in the Lucan Passion Narrative. In Semeia, No 69-70, pp. 33-60.

Clark, Katerina and Holquist, Michael. 1984. Mikhail Bakhtin. Cambridge, Mass.: Harvard University Press.

Coates, Ruth 1998. Christianity in Bakhtin: God and the Exiled Author. Cambridge: Cambridge University Press.

Craddock, Fred B 1990. Luke: Interpretation. Louisville, Kentucky: John Knox Press.

Danow, DK 1991. The Thought of Mikhail Bakhtin: From Word to Culture. New York: St Martin's.

Dentith, Simon 1996. Bakhtinian Thought: An Introductory Reader. London: Routledge.

Emerson, Caryl. Keeping the Self Intact During the Culture Wars: A Centennial Essay for Mikhail Bakhtin. In New Literary History, Vol. 27, pp.107-26.

Emerson, Caryl 1997. The First Hundred Years of Mikhail Bakhtin. Princeton, New Jersey: Princeton University Press.

Green, Barbara 2000. Mikhail Bakhtin and Biblical Scholarship: An Introduction. Atlanta, Georgia: Society of Biblical Literature.

Green, Joel B 1995. The Theology of the Gospel of Luke. Cambridge: Cambridge University Press. 
Hanson, Paul D 1975. The Dawn of Apocalyptic. Philadelphia: Fortress Press.

Holquist, Michael 1981. Introduction to Bakhtin, Mikhail Mikhailovich, The Dialogic Imagination: Four Essays translated by Caryl Emerson and Michel Holquist (ed.) Austin: University of Texas Press.

Josephus, 1959. The Jewish War, translated by GA Williamson. Middlesex: Penguin Plutarch. 1919 Alexander. In Plutarch's Lives, Dryden Edition, Vol.2. London: JM Dent\&Sons. Marshall, I Howard 1978. The Gospel of Luke: A Commentary on the Greek Text. Exeter Paternoster Press/Wm. B. Eerdmans Publishing Co.

Moore, Stephen, D 1987. Are the Gospels Unified Narratives? In SBLSP 26, ed. KH Richards, 443-458. Atlanta: Scholars Press.

Moore, Stephen, D 1989. Literary Criticism and the Gospels: The Theoretical Challenge. New Haven: Yale University Press.

Morson, Gary Saul and Emerson, Caryl 1990. Mikhail Bakhtin: Creation of a Prosaics. Stanford: Stanford University Press.

Newsom, Carol A 1996. Bakhtin, the Bible and Dialogic Truth. In The Journal of Religion, Vol. 76, pp. 290-306.

Praeder, Susan Marie 1981. Luke-Acts and the Ancient Novel. In SBL 1981 Seminar Papers. Chico USA: Scholars Press.

Robbins, Vernon K 1981. Laudation Stories in the Gospel of Luke and Plutarch's Alexander. in Society for Biblical Literature Seminar Papers. USA: Scholars Press.

Stern, Menahem. 1987. Josephus and the Roman Empire as Reflected in The Jewish War. In Josephus, Judaism, and Christianity. Feldman, Louis H, Hata, Gohei (eds.). Detroit, Michigan: Wayne State University Press.

Suetonius 1957. The Twelve Caesars, translated by Robert Graves. Grant, Michael (Revised and Introd.). Harmondsworth, Middlesex, England: Penguin.

Suetonius 1982. Divus Augustus. Carter, John M (ed.). Bristol: Classical Press.

Tacitus 1964. The Histories, translated by Kenneth Wellesly, Radice, Betty (ed.).

Harmondsworth, Middlesex, England: Penguin.

Talbert, Charles H 1974. Literary Patters, Theological Themes and the Genre of Luke Acts. Montana: Scholars Press.

Talbert, Charles H 1977. What is a Gospel?: The Genre of the Canonical Gospels. Philadelphia: Fortress.

Talbert, Charles H 1986. Reading Luke: A Literary and Theological Commentary on the Third Gospel. New York: The Crossroad Publishing Company.

Talbert, Charles H 1989. Luke-Acts. In The New Testament and its Modern Interpreters. Epp, Eldon Jay, MacRae, George W (eds.). Philadelphia: Fortress Press.

Tannehill, Robert C 1986. The Narrative Unity of Luke-Acts: A Literary Interpretation Vol 1: The Gospel according to Luke. Philadelphia: Fortress Press.

Tihanov, Galin 1998. Bakhtin's Essays on the Novel (1935-41): A Study of their Intellectual Background and Innovativeness. Dialogism 1 (1998) pp. 30-56.

Todorov, Tzvetan 1984. Mikhail Bakhin: The Dialogic Principle, translated by WladGodzich. Theory and History of Literature Vol. 13. Minneapolis: University of Minnesota Press.

Versnel, HS 1986. Greek Myth and Ritual: The Case of Kronos. In Interpretations of Greek Mythology. Bremmer, Jan (ed.), pp. 121-152. Totowa, New Jersey: Barnes and Noble Books. 
Williams, Howard (ed. and trans.) 1900. Lucian's Dialogues, namely The Dialogues of the Gods, of the Sea-Gods, and of the Dead; Zeus the Tragedian, the Ferry-Boat, etc. London: George and Sons.

Wilson, Brian E 1991. Synoptic Format Phenomena. A paper read at the 2001 International meeting of the Society of Biblical Literature. Rome: Pontifical Gregorian University. Wilson, SG 1983. Luke and the Law. Cambridge: Cambridge University Press. 